\title{
Retraction: effectiveness of option $B$ highly active antiretroviral therapy (HAART) prevention of mother-to-child transmission (PMTCT) in pregnant HIV women
}

\author{
Erastus K Ngemu', Christopher Khayeka-Wandabwa², Eliningaya J Kweka ${ }^{3 *}$, Joseph K Choge ${ }^{4}$, Edward Anino ${ }^{1}$ and \\ Elijah Oyoo-Okoth ${ }^{5}$
}

\section{Retraction}

This article [1] has been retracted by the editors of $B M C$ Research Notes because, contrary to the statement in the manuscript, Moi University Institutional Research and Ethics Committee (IREC) has confirmed that ethics approval was not obtained to conduct this study. In addition, the authors did not have permission to use data from the DREAM program.

\footnotetext{
Author details

'School of Science, Department of Biochemistry, University of Eldoret, P.O Box 1125, Eldoret, Kenya. ${ }^{2}$ Institute of Tropical Medicine and Infectious Diseases (ITROMID), Jomo Kenyatta University of Agriculture and Technology (JKUAT), Nairobi, Kenya. ${ }^{3}$ Tropical Pesticides Research Institute, Division of Livestock and Human Diseases Vector Control, Mosquito Section, Ngaramtoni, Off Nairobi road, P.O. Box 3024, Arusha, Tanzania. ${ }^{4}$ School of Health Sciences, University of Eastern Africa, Baraton, P.O Box 2500-30100, Eldoret, Kenya. ${ }^{5}$ School Natural Resources and Environmental Studies, Karatina University, P.O. Box 1957-10101, Karatina, Kenya.
}

Received: 20 November 2014 Accepted: 20 November 2014 Published: 25 November 2014

\section{Reference}

1. Ngemu EK, Khayeka-Wandabwa C, Kweka EJ, Choge JK, Anino E, Oyoo-Okoth E: Effectiveness of option B highly active antiretroviral therapy (HAART) prevention of mother-to-child transmission (PMTCT) in pregnant HIV women. BMC Res Notes 2014, 7:52.

\section{doi:10.1186/1756-0500-7-868}

Cite this article as: Ngemu et al:: Retraction: effectiveness of option B highly active antiretroviral therapy (HAART) prevention of mother-tochild transmission (PMTCT) in pregnant HIV women. BMC Research Notes 2014 7:868.

\footnotetext{
* Correspondence: Pat.kweka@gmail.com

${ }^{3}$ Tropical Pesticides Research Institute, Division of Livestock and Human Diseases Vector Control, Mosquito Section, Ngaramtoni, Off Nairobi road, P.O.
} Box 3024, Arusha, Tanzania

Submit your next manuscript to BioMed Central and take full advantage of:

- Convenient online submission

- Thorough peer review

- No space constraints or color figure charges

- Immediate publication on acceptance

- Inclusion in PubMed, CAS, Scopus and Google Scholar

- Research which is freely available for redistribution

Submit your manuscript at www.biomedcentral.com/submit
Ciomed Central
() Biomed Central

(c) 2014 Ngemu et al.; licensee BioMed Central Ltd. This is an Open Access article distributed under the terms of the Creative Commons Attribution License (http://creativecommons.org/licenses/by/4.0), which permits unrestricted use, distribution, and reproduction in any medium, provided the original work is properly credited. The Creative Commons Public Domain Dedication waiver (http://creativecommons.org/publicdomain/zero/1.0/) applies to the data made available in this article unless otherwise stated. 